\title{
Indolbutyric Acid and Time of the Year Influence on Rooting of Chrysanthemum Cuttings
}

\author{
Marina Romano Nogueira1, Marcos Vieira Ferraz', Amanda Kelly Dias Bezerra1, \\ Renata Bachin Mazzini-Guedes ${ }^{2}$, Carla Rafaele Xavier Costa1, Lívia Caroline Praseres de Almeida1, \\ Suzana Targanski Sajovic Pereira1, Kathia Fernandes Lopes Pivetta1
}

${ }^{1}$ Department of Plant Production, São Paulo State University (Unesp), Jaboticabal, Brazil

${ }^{2}$ Federal University of Paraná (UFPR), Jandaia do Sul, Brazil

Email: ferrazmarcos@yahoo.com.br

How to cite this paper: Nogueira, M.R., Ferraz, M.V., Bezerra, A.K.D., MazziniGuedes, R.B., Costa, C.R.X., de Almeida, L.C.P., Pereira, S.T.S. and Pivetta, K.F.L. (2018) Indolbutyric Acid and Time of the Year Influence on Rooting of Chrysanthemum Cuttings. American Journal of Plant Sciences, 9, 507-516.

https://doi.org/10.4236/ajps.2018.93038

Received: December 27, 2017

Accepted: February 24, 2018

Published: February 27, 2018

Copyright (๑) 2018 by authors and Scientific Research Publishing Inc. This work is licensed under the Creative Commons Attribution International License (CC BY 4.0).

http://creativecommons.org/licenses/by/4.0/

\begin{abstract}
The objective of this study was to analyze the effect of the seasons and indol butyric acid (IBA), as well as the preparation of IBA solutions on rooting growth of "Fine Time" chrysanthemum cuttings. The first experiment was arranged in a $4 \times 2$ factorial scheme: IBA concentrations $(0,1000,2000$ and $\left.3000 \mathrm{mg} \cdot \mathrm{L}^{-1}\right)$ during summer and winter with 4 replicates of two pots and six cuttings per pot. In the second experiment, the storage of IBA solution (1000 $\mathrm{mg} \cdot \mathrm{L}^{-1}$ ) at $15^{\circ} \mathrm{C}$ was studied with four replicates of 10 cuttings per plot in a period of four weeks. In the third experiment, dilution and supply of IBA (1000 mg. $\mathrm{L}^{-1}$ or $1000 \mathrm{mg} \cdot \mathrm{kg}^{-1}$ ) were studied; there were eight treatments: (1) IBA mixed with industrial talc; (2) IBA diluted in $50 \%$ alcohol and oven dried at $30^{\circ} \mathrm{C}$; (3) IBA diluted in $50 \%$ alcohol and oven dried at $70^{\circ} \mathrm{C}$; (4) IBA diluted in $\mathrm{NaOH}$ and supplied via aqueous solution; (5) IBA diluted in acetone and supplied via aqueous solution; (6) IBA diluted in alcohol $92.8 \%$ and supplied via alcoholic solution; (7) IBA diluted in alcohol 50\% and supplied via alcoholic solution; (8) IBA mixed and supplied via lanolin; with four replicates of 10 cuttings per plot. Twenty-one days after cutting implementation, the following variables were evaluated: rooting percentage, number, average length and root dry mass. Statistical analysis and time-of-year averages were compared using the Tukey test at 5\%; polynomial regression for IBA concentration and preparation data. The means of dilution and delivery were compared by the Scott-Knott test. Treatment with IBA at a concentration of 3000 $\mathrm{mg} \cdot \mathrm{kg}^{-1}$ resulted in $90 \%$ rooting in the winter and $100 \%$ in the summer for all treatments. Results suggest the concentration of $2000 \mathrm{mg} \cdot \mathrm{L}^{-1}$ in the summer and 2000 and $3000 \mathrm{mg} \cdot \mathrm{L}^{-1}$ during the winter provided better quality for the
\end{abstract}


root system. Cuttings treated with IBA diluted in 50\% alcohol and oven dried at $30^{\circ} \mathrm{C}$ showed higher number, length and vigor of the roots.

\section{Keywords}

Dendranthema grandiflora, Cutting, Asexual Propagation

\section{Introduction}

Chrysanthemum (Dendranthema grandiflora Tzvelev), from the Asteraceae family, is considered one of the most important flowers for both cutting and potting in several countries around the world [1].

The producer's experience, along with research results made over the years, has already defined many criterions to maximize the process of production of chrysanthemum seedlings, which is currently successfully carried out. However, the renewal of cultivars is very intense, and some problems may arise, such as a lower percentage of rooting of the cuttings, which limit good part of production.

The low percentage of rooting is a serious problem for the potted chrysanthemum because the cuttings are rooted in the definitive pot and the rooting unevenness. Consequently it will reflect on the unevenness of the final product.

The commercial propagation of chrysanthemum is done by rooting of herbaceous cuttings previously treated with synthetic auxin, with indol butyric acid (IBA) being the most used, at a concentration of $1000 \mathrm{mg} \cdot \mathrm{L}^{-1}$.

According to reports from producers, "Fine Time" cuttings, which are a pot cultivar with yellow inflorescences and of great acceptance in the Brazilian market, do not root satisfactorily in the winter.

Although staking is a method that has many advantages [2], it also presents factors not yet fully elucidated, which affect the rooting process, even among specimens of the same species. This technique of vegetative propagational lied to substances that promote the increase of rooting helps to improve the use of the species with productivity gains [3]. Among the substances used for this purpose, auxins may increase the rhizogenic response, depending on their concentration [4].

Auxin can be given via powder, via concentrated solution (rapid immersion) and diluted solution. Almeida et al. [5] tested the supply of IBA via powder and liquid solution (rapid immersion) in the minicutting rooting of Eucalyptus cloeziana clones and did not find significant differences between the two forms of supply. Cuquel et al. [6] observed that the solid carrier was more efficient at rooting chrysanthemum cuttings when compared to the concentrated solution (alcohol base). Hartmann et al. [2] also consider that talc preparations have the advantage of being practical in use.

Another fact that must be observed is the time of collection of the propagating material, since the donor plant is directly related to the rooting capacity of the propagation material, due to the greater or lesser synthesis of the hormone, and 
the due influence of environmental factors that the donor plants are submitted to [7].

The end of the dry season was the most favorable for the rooting of Euplassainaequalis [8] in Drimys brasiliensis was the coldest time for the collection of herbaceous cuttings without the addition of IBA [9].

The association of these techniques can have a positive result. For example, Sapium glandulotum obtained higher rooting percentages with the application of $4000 \mathrm{mg} \cdot \mathrm{L}^{-1}$ of IBA in the winter, whereas the addition of 2000, 6000 and 8000 $\mathrm{mg} \cdot \mathrm{L}^{-1}$ of this auxin at the same time of year did not have satisfactory results [10].

Therefore, auxin may have varied responses depending on the picking season, promoting and/or inhibiting the rooting process [11] and in some species it becomes phytotoxic [7].

Thus, the objective of this work was to study the effect of indol butyric acid (IBA) along with the seasons of the year, as well as the preparation of IBA solutions and form of rooting of "Fine Time" chrysanthemum cuttings.

\section{Material and Methods}

Three experiments were carried out using the cultivar "Fine Time", which cuttings presented approximately $5 \mathrm{~cm}$ in length and, on average, 5 leaves. In all three experiments the experimental design was completely randomized.

In the first experiment, the treatments were arranged in a $4 \times 2$ factorial scheme: four IBA concentrations $\left(0,1000,2000\right.$ and $\left.3000 \mathrm{mg} \cdot \mathrm{L}^{-1}\right)$ combined with two seasons of the year (summer and winter), with 4 replicates; each plot consisted of two pots, with six cuttings in each pot.

The experiment was carried out in a greenhouse in the Company "Johanna M.H.B. v. d. Broek", Holambra, São Paulo State, Brazil, located at $22^{\circ} 38^{\prime}$ latitude south and at $47^{\circ} 03^{\prime}$ longitude to the west and at an altitude of 600 meters above sea level, where the climate is the Cwa type of Köppen, that is, humid subtropical with drought in winter, in two seasons, winter and summer.

In this first experiment, the cuttings were treated with IBA via powder, placing their bases to about $2 \mathrm{~cm}$ in a container containing the previously homogenized mixture of industrial talc and IBA.

They were planted in clay pots with $15 \mathrm{~cm}$ of superior diameter, with uniform 105 spacings between cuttings, which were placed at about $1.5 \mathrm{~cm}$ depth, in a substrate with $106 \mathrm{pH} 5.9$ and electroconductivity (EC) of $0.88 \mathrm{mS} / \mathrm{cm}$, composed of $30 \%$ pinus, $30 \%$ red soil, $20 \%$ xaxim fiber and $20 \%$ earthworm humus. After the cutting process was finished, pots were well watered and then covered with a clear plastic.

The rooting phase is considered vegetative, that is, $\mathrm{LD}$ phase (long days); therefore, intermittent artificial lighting was provided for 8 hours per day with a $100 \mathrm{~W}(220 \mathrm{~V})$ incandescent light, providing a luminous intensity of approximately 1200 lux. 
The second and third experiments were carried out in a greenhouse covered with a coated plastic structure at São Paulo State University-UNESP, Jaboticabal, São Paulo State, Brazil at $21^{\circ} 15^{\prime} 03^{\prime \prime}$ south latitude and $48^{\circ} 19^{\prime} 03^{\prime \prime}$ longitude to the west and at an altitude of 615 meters above sea level, whose climate is the Cwa type of Köppen, which is, humid subtropical with drought in winter, in both season, winter and summer.

In these two experiments the cutting process was carried out in plastic trays $(14.0 \times 18.5 \times 8.0 \mathrm{~cm})$, containing vermiculite of medium moist granulometry. The containers were wrapped in transparent plastic bags in order to maintain a high humidity during rooting. Throughout the experimental period, intermittent artificial lighting was provided for 8 hours per day, with a $100 \mathrm{~W}(220 \mathrm{~V})$ incandescent lamp, providing a luminous intensity of approximately 1200 lux.

In the second experiment the storage of the IBA solution $\left(1000 \mathrm{mg} \cdot \mathrm{L}^{-1}\right)$ at $15^{\circ} \mathrm{C}$ during different periods $(0,7,14,21$ and 28 days) was studied using five treatments and four replicates of 10 cuttings.

In the third experiment, dilution and supply of IBA $\left(1000 \mathrm{mg} \cdot \mathrm{L}^{-1}\right.$ or 1000 $\mathrm{mg} \cdot \mathrm{kg}^{-1}$ ) were studied; there were eight treatments: (1) IBA mixed with industrial talc, without dilution; (2) IBA diluted in $50 \%$ alcohol and oven dried at $30^{\circ} \mathrm{C}$; (3) IBA diluted in $50 \%$ alcohol and oven dried at $70^{\circ} \mathrm{C}$; (4) IBA diluted in $\mathrm{NaOH}$ and supplied via aqueous solution; (5) IBA diluted in acetone and supplied via aqueous solution; (6) IBA diluted in alcohol 92.8\% (market) and supplied via alcoholic solution; (7) IBA diluted in alcohol $50 \%$ and supplied via alcoholic solution; (8) IBA mixed and supplied via lanolin; four replicates of 10 cuttings/plot were used.

Treatment 1 , via industrial powder, was performed by dry mixing the talc and IBA, where both were placed in the same container and shaken manually. In the other treatments, except for lanolin, the corresponding dilutions and subsequent mixing were performed. The preparation of the treatment consisted of the addition of IBA to lanolin, by means of circular movements until obtaining a homogeneous mixture. Next, the bases of the cuttings (about $2.0 \mathrm{~cm}$ ) were immersed in the respective containers, treating them with the previously homogenized mixtures, performing the cutting after each treatment.

For all the experiments, the evaluation was performed 21 days after cutting, observing the number of rooted cuttings, number of roots per cutting, average length of roots per cutting $(\mathrm{cm})$ and dry mass of roots per cutting $(\mathrm{mg})$.

To evaluate the dry mass of the roots, the material was oven dried at $70^{\circ} \mathrm{C}$ until it remained in a constant mass, using a precision digital scale (four decimal digits) for weighing.

For a statistical purpose the rooting percentage data were transformed into $\arcsin (\mathrm{x} / 100) \quad 1 / 2$ and number of roots in $(\mathrm{x}+1) 1 / 2$; the mean of the root length and root dry mass were not transformed.

The data collected was analyzed statistically, and analysis of variance was used when applicable. The unfolding degrees of freedom of IBA concentrations were 
performed to evaluate the polynomial regression, in order to verify the pattern of the variables in concentration of IBA. A polynomial regression for the storage data was also performed and for dilution and supply, the means were compared using the Scott-Knott's Test.

\section{Results and Discussion}

The interaction between IBA concentrations and time of year was found to be significant. In the summer the rooting percentage was $100 \%$ for all treatments and in the winter, $79 \%$ on average (Table 1 ).

The interaction between the IBA treatment and the time of year was significant for root numbers, root mean length and root dry mass per cutting and, for all traits, higher mean values were observed in the summer (Table 1). However, there was a variation in relation to IBA concentration.

In the winter, the concentration of $3000 \mathrm{mg} \cdot \mathrm{kg}^{-1}$ gave the highest percentage of rooting (91\%), as shown in Figure 1(a).

The coldest season was also the most suitable for the collection of cuttings of Drimysbrasiliensis, however, Zem et al. [9] observed that it was not necessary to add IBA, already in Psychotrianuda [12]. The most appropriate time for picking was during the summer, but not differing from the spring collection, similar from the previous study

Contrary to the result found, Pivetta et al. [13] observed that rooting of Nerium oleander cuttings in white and pink flower varieties was superior in the summer. Justifying the intense period of vegetative growth, facilitating the development of roots in species with difficulty to root.

It was found that for root numbers, during the summer higher averages were observed at the concentration of $2000 \mathrm{mg} \cdot \mathrm{kg}^{-1}$, decreasing with $3000 \mathrm{mg} \cdot \mathrm{kg}^{-1}$; in the winter, higher averages were observed with $2000 \mathrm{mg} \cdot \mathrm{kg}^{-1}$ and $3000 \mathrm{mg} \cdot \mathrm{kg}^{-1}$ (Figure 1(b)). It was observed, therefore, that the IBA interfered positively with the number of roots, both in the winter and in the summer.

Stuepp et al. [14] studying IBA effect on Ilex paraguariensis demonstrated that autumn is the most enabling season for cuttings rooting, followed by spring and winter.

Xavier et al. [3] stated that the exogenous auxin when applied at the base of the cuttings propitiates for faster promotion of the adventitious root initiation.

Table 1. Means obtained from the analysis of variance for rooting percentage, number of roots (NR), mean length (ML) and dry mass (DM) of roots in "Fine Time" chrysanthemum cuttings planted in summer and winter.

\begin{tabular}{ccccc}
\hline Means & Rooting $(\%)$ & NR & ML $(\mathrm{cm})^{3}$ & DM $(\mathrm{mg})^{3}$ \\
\hline Summer & $90^{1}(100)^{3} \mathrm{a}$ & $4.51^{2}(12.32) \mathrm{a}$ & $4.74 \mathrm{a}$ & $3.54 \mathrm{a}$ \\
Winter & $63(79) \mathrm{b}$ & $3.26(5.11) \mathrm{b}$ & $2.61 \mathrm{~b}$ & $2.19 \mathrm{~b}$ \\
$\mathrm{CV}(\%)$ & & 8.00 & 10.92 & 15.56
\end{tabular}

${ }^{1 /}$ Data transformed into $\arcsin (\mathrm{x} / 100)^{1 / 2} \cdot{ }^{2 /}$ Data transformed into $(\mathrm{x}+1)^{1 / 2} \cdot{ }^{3 /}$ Unprocessed data. Means followed by different letter in the column differ from each other by the Tukey test at $5 \%$ probability. 


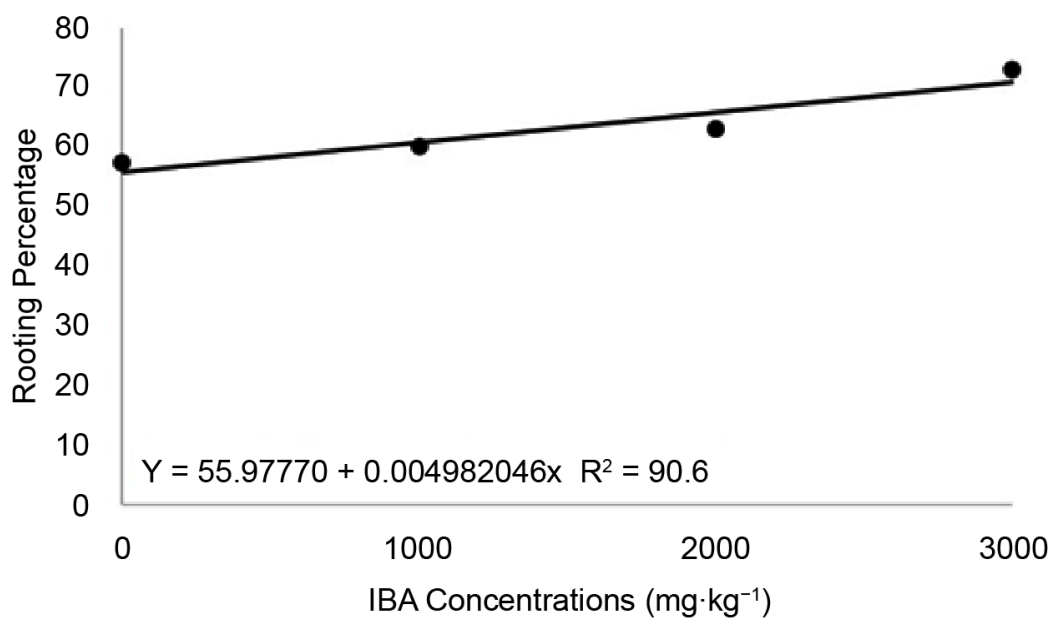

(a)

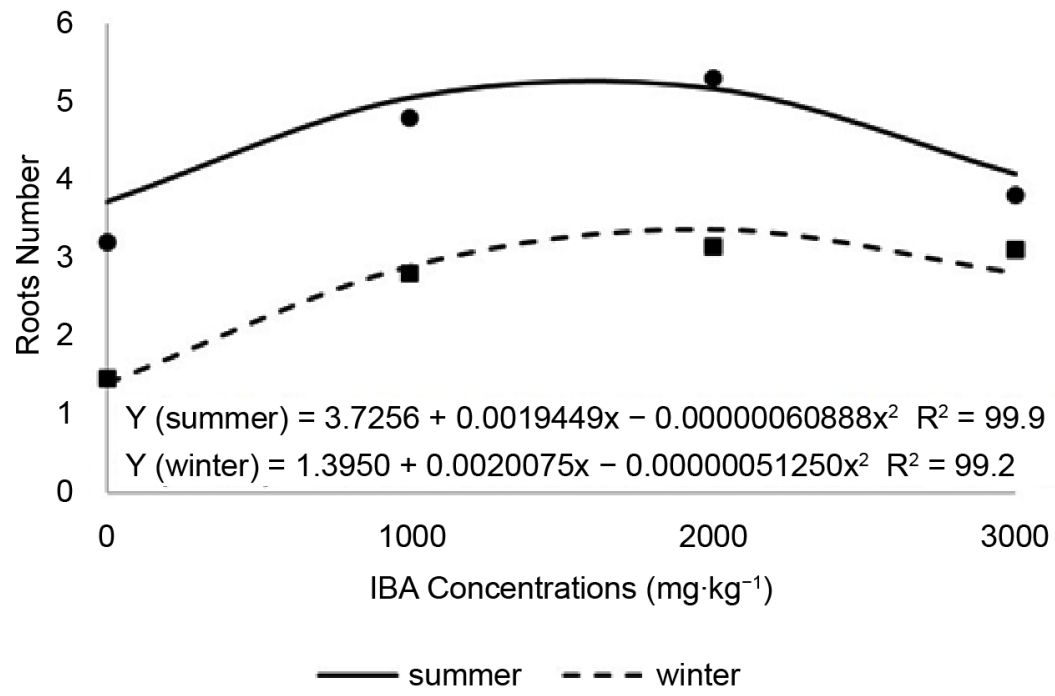

(b)

Figure 1. Regression curve between IBA concentrations ( $\left.\mathrm{mg} \cdot \mathrm{kg}^{-1}\right)$ and: (a) percentage of rooting in winter; (b) root number (data transformed into arcsin $(\mathrm{x} / 100)^{1 / 2}$ in summer and winter for "Fine Time" chrysanthemum cuttings.

Therefore, it is believed that this fact can favor the obtaintion of greater lengths of roots of the cuttings [15], as it is possible to observe the behavior of the curve. There was an increase of the length of the roots of chrysanthemum with the increasing of IBA in this study (Figure 1(a)).

There was no regression adjustment for the mean length and dry mass of roots in the summer and winter. There was a quadratic regression adjustment for the root length mean (Figure 2(a)) and cubic for root dry mass (Figure 2(b)) for both characteristics higher concentrations were observed at the concentration of $2000 \mathrm{mg} \cdot \mathrm{kg}^{-1}$.

Pivetta et al. [13] still observed that the number and length of roots was higher in the winter period for Nerium oleander for pink flowers, however, the dry mass of roots was higher in the winter. 


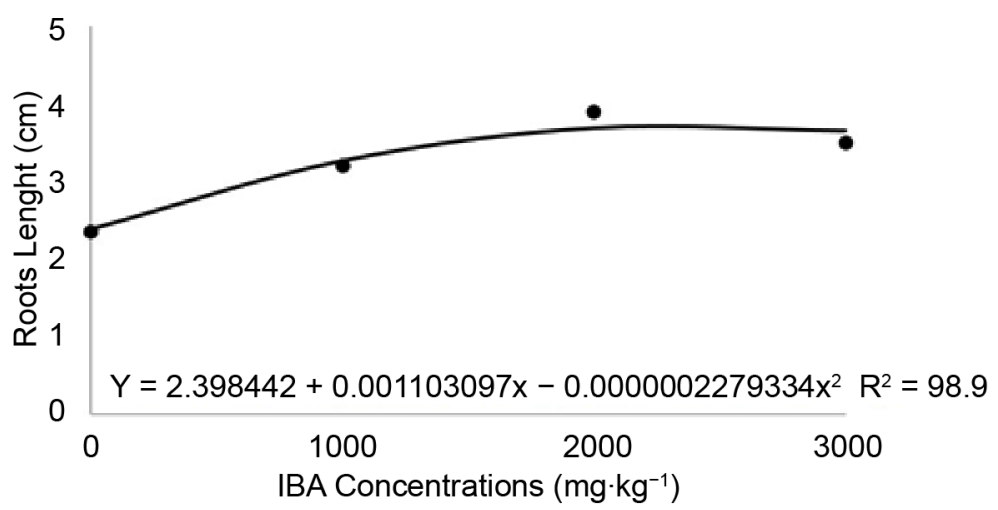

(a)

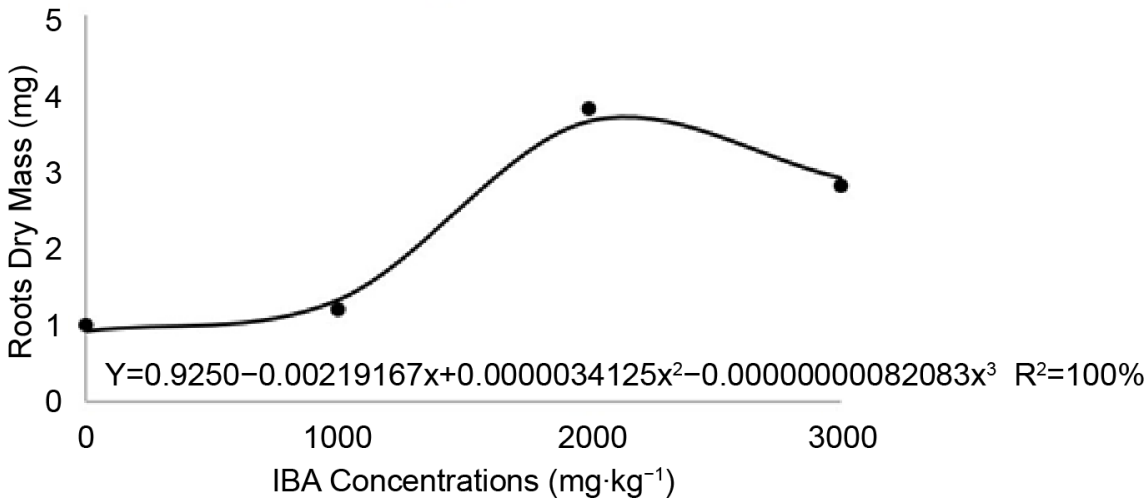

(b)

Figure 2. Regression curve between IBA concentrations $\left(\mathrm{mg} \cdot \mathrm{kg}^{-1}\right)$ and: (a) average root length in $\mathrm{cm}$ in winter and (b) root dry mass, in g, in winter for "Fine Time" chrysanthemum cuttings.

Regarding the storage of the solution at the concentration of $1000 \mathrm{mg} \cdot \mathrm{L}^{-1}$ at $15^{\circ} \mathrm{C}$ for up to four weeks, it was observed that there was no significance for any of the characteristics evaluated. For instance, the storage period did not interfere with the percentage or the quality of the root system. On average the rooting percentage was $100 \%$; number of roots, 5.2 ; mean root length $1.6 \mathrm{~cm}$ and root dry mass, $0.0585 \mathrm{mg}$. However, the study was carried out in the summer, when this cultivar does not present problems in the rooting of the cuttings.

However, the variables that are related to root system quality, number, average length and dry mass of chrysanthemum roots were influenced by the treatments (Table 2).

Similarly, Oliveira et al. [16], comparing alcohol $50 \%$ and $\mathrm{NaOH}$ as vehicles for IBA supply in olive cuttings, also observed that the treatments did not differ significantly in rooting percentage. Also, Almeida et al. [5] did not find significant differences between the supply of IBA via powder and liquid solution (rapid immersion) in the rooting of minicuttings of eucalyptus clones.

Likewise, working with the rooting of chrysanthemum cuttings, Cuquel et al. [6] observed that the solid carrier was more efficient at rooting when compared to the concentrated solution (alcohol base). These differences may be related to the cultivar. 
Table 2. Average squares, and averages obtained for rooting percentage, number (NR), average length (AL) and dry mass (DM) of "Fine Time" roots chrysanthemum cuttings under the influence of different forms of indole butyric acid supply.

\begin{tabular}{ccccc}
\hline Causes of variation & Rooting $(\%)$ & NR & AL $(\mathrm{cm})$ & DM $(\mathrm{mg})$ \\
\hline Powder-undiluted mixture & $64.43^{1}(81.37) \mathrm{a}$ & $3.26^{2}(7.56)^{3} \mathrm{a}$ & $1.50^{3} \mathrm{~b}$ & $0.05 \mathrm{a}$ \\
Dry powder at $30^{\circ} \mathrm{C}$ & $60.11(75.16) \mathrm{a}$ & $4.23(13.91) \mathrm{a}$ & $1.31 \mathrm{~b}$ & $0.06 \mathrm{a}$ \\
Dry powder at $70^{\circ} \mathrm{C}$ & $74.14(92.53) \mathrm{a}$ & $2.46(3.84) \mathrm{c}$ & $2.35 \mathrm{a}$ & $0.05 \mathrm{a}$ \\
$\mathrm{NaOH}$ & $51.33(60.95) \mathrm{a}$ & $3.02(6.35) \mathrm{b}$ & $1.30 \mathrm{~b}$ & $0.04 \mathrm{~b}$ \\
Acetone & $52.49(62.92) \mathrm{a}$ & $3.32(7.95) \mathrm{b}$ & $1.33 \mathrm{~b}$ & $0.06 \mathrm{a}$ \\
Alcohol 92.8\% & $54.22(65.81) \mathrm{a}$ & $2.04(2.37) \mathrm{c}$ & $1.78 \mathrm{a}$ & $0.02 \mathrm{~b}$ \\
Alcohol 50\% & $57.47(71.08) \mathrm{a}$ & $2.70(4.84) \mathrm{c}$ & $1.13 \mathrm{~b}$ & $0.03 \mathrm{~b}$ \\
Lanolin & $60.86(76.28) \mathrm{a}$ & $2.58(4.32) \mathrm{c}$ & $1.98 \mathrm{a}$ & $0.04 \mathrm{~b}$ \\
$\mathrm{CV}(\%)$ & 24.03 & 14.61 & 20.35 & 33.69 \\
\hline
\end{tabular}

${ }^{1 /}$ Data transformed into $\arcsin (\mathrm{x} / 100)^{1 / 2} .{ }^{2 /}$ Data transformed into $(\mathrm{x}+1){ }^{1 / 2} \cdot{ }^{3 /}$ Unprocessed data. Means followed by the same letter in the column do not differ from each other by the Skott-Knott test at $5 \%$ probability.

Observing the rooting of woody cuttings of Vitisrotundifoliacvs Magnolia and Topsail, Biasi and Boszczowski [17], found that the percentages of rooting using $10 \%$ ethanolic solution in the control were inferior to those obtained in the experiment with IBA in the form of talc, justifying that the ethanolic solution may have been very strong for the cuttings.

Analyzing the difference between the number of roots formed as a function of the different treatments (Table 2), it was observed that the treatments with powder, without dilution and dry at $30^{\circ} \mathrm{C}$ were the ones with the highest number. The lowest average was obtained in the mixture with $92.8 \%$ alcohol, which may have damaged some cells of the base of the cuttings, which impaired the induction of a greater number of root primordia.

In this study, the use of $\mathrm{NaOH}$ as a diluent provided a higher number of roots when compared to $50 \%$ alcohol, unlike what was found by Oliveira et al. [16] for olive cuttings; When comparing alcohol $50 \%$ and $\mathrm{NaOH}$ as vehicles for IBA supply in olive cuttings the authors observed that the treatments did not differ significantly in the number of roots. The $50 \%$ alcohol did not damage cells from the bases of the olive cuttings, however, it may have damaged the "Fine Time" chrysanthemum cuttings due to the more herbaceous consistency of this material.

The analysis of root mean length (Table 2) showed a significant difference between the treatments. The treatment dry powder at $70^{\circ} \mathrm{C}$, alcohol $92.8 \%$ and lanolin presented higher averages when compared with the others. The lowest mean length, $1.30 \mathrm{~cm}$, was observed with $\mathrm{NaOH}$ treatment.

Oliveira et al. [16], comparing alcohol $50 \%$ and $\mathrm{NaOH}$ as vehicles for IBA supply in olive cuttings, observed that the treatments did not differ significantly in the mean of root length. 
The IBA supply via undiluted powder, via dry powder at $30^{\circ} \mathrm{C}$, via dry powder at $70^{\circ} \mathrm{C}$ and diluted in acetone were the ones that presented the highest average dry mass of roots per cutting (Table 2).

In a general analysis, the diluents and the forms of preparation and supply of indole butyric acid did not influence the percentage of rooting of cuttings of "Fine Time" chrysanthemum, however, they interfered with the development of the root system. It can be observed (Table 2) that the treatments that had cuttings with greater number of roots, presented smaller but more vigorous roots (greater dry mass) except for the treatment via dry powder at $70^{\circ} \mathrm{C}$, where it was observed a smaller number of roots, but greater length and dry mass. Considering that cuttings with a greater number of roots and greater vigor are preferred for the production of seedlings, treatments that have provided IBA via powder, undiluted or diluted in 50\% hydroalcoholic solution and dried at a temperature of $30^{\circ} \mathrm{C}$, may be considered the most ideal to improved root system development. The aerial part was not affected in any of the treatments.

\section{Conclusions}

Treatment with IBA at the concentration of $3000 \mathrm{mg} \cdot \mathrm{kg}^{-1}$ provided $90 \%$ of rooting in the winter and $100 \%$ in the summer for all treatments.

In the summer, the concentration of $2000 \mathrm{mg} \cdot \mathrm{kg}^{-1}$ and in the winter, 2000 and $3000 \mathrm{mg} \cdot \mathrm{kg}^{-1}$ provided better quality of the root system.

Cuttings treated with IBA diluted in $50 \%$ alcohol and oven dried at $30^{\circ} \mathrm{C}$ showed higher number, length and vigor of the roots.

\section{References}

[1] Kumbar, I., Patil, C.P., Kulkarni, B.S., Shiragur, M. and Shirol, A.M. (2017) Efficacy of Entrophospora sp. (VA Mycorrhiza) on Salt Tolerance and Flower Yield and Quality of Chrysanthemum var. Marigold [Dendranthema grandiflora Tzvelev.]. International Journal of Current Microbiology and Applied Sciences, 6, 4769-4777. https://doi.org/10.20546/ijcmas.2017.610.443

[2] Hartmann, H.T., Kester, D.E., Davies Jr., F.T. and Geneve, R.L. (2011) Plant Propagation: Principles and Practices. 8th Edition, Prentice Hall, New Jersey, 915 p.

[3] Xavier, A., Wendling, I. and Silva, R.L. (2009) Silvicultura clonal: Princípios e técnicas. Editora UFV, Viçosa, MG, 272 p.

[4] Goulart, P.B., Xavier, A.E. and Cardoso, N.Z. (2008) Efeito dos reguladores de crescimento AIB e ANA no enraizamento de miniestacas de clones de Eucalyptus grandis $\mathrm{x}$ Eucalyptus urophylla. Revista Árvore, 32, 1051-1058. https://doi.org/10.1590/S0100-67622008000600010

[5] Almeida, F.D., Xavier, A., Dias, J.M.M. and Paiva, H.N. (2007) Eficiência das auxinas (AIB e ANA) no enraizamento de miniestacas de clones de Eucalyptus cloeziana F. Muell. Revista Árvore, 31, 455-463.

https://doi.org/10.1590/S0100-67622007000300011

[6] Cuquel, F.L., Granja, N.P. and Minami, K. (1992) Avaliação do enraizamento de estacas de crisântemo (Chrysanthemum morifolium L.) cv. white Reagan 606 tratadas com ácido indolbutírico (IBA). Scientia Agricola, 49, 15-22. 
[7] Zuffellato-Ribas, K.C. and Rodrigues, J.D. (2001) Estaquia: Uma abordagem dos principais aspectos fisiológicos. K. C. Zuffellato-Ribas, Curitiba, 39 p.

[8] Oliveira, M.C. and Ribeiro, J.F. (2013) Enraizamento de estacas de Euplassainaequalis (Pohl) Engl. de mata de galeria em diferentes estações do ano. Bioscience Journal, 29, 991-999.

[9] Zem, L.M., Weiser, A.H., Zuffellato-Ribas, K.C. and Radomski, M.I. (2015) Estaquia caulinar herbácea e semilenhosa de Drimys brasiliensis. Revista Ciência Agronômica, 46, 396-403.

[10] Ferreira, B.G.A., Zuffellato-Ribas, K.C., Wendling, I., Koehler, H.S. and Nogueira, A.C. (2010) Miniestaquia de Sapium glandulatum (Vell.) Pax com o uso de ácido indol butírico e ácido naftaleno acético. Ciência Florestal, 20, No. 1.

https://doi.org/10.5902/198050981758

[11] Fischer, D.L.O., Fachinello, J.C., Antunes, L.E.C., Tomaz, Z.F.P. and Giacobbo, C.L. (2008) Efeito do ácido indolbutírico e da cultivar no enraizamento de estacas lenhosas de mirtilo. Revista Brasileira de Fruticultura, 30, 285-289. https://doi.org/10.1590/S0100-29452008000200003

[12] Nery, F.D.S.G., Zuffellato-Ribas, K.C. and Koehler, H.S. (2014) Enraizamento de Psychotria nuda (Cham. \& Schltdl.) Wawra (Rubiaceae) nas quatro estações do ano. Ciência Florestal, 24, 243-250. https://doi.org/10.5902/1980509813341

[13] Pivetta, K.F.L., Pedrinho, D.R., Fávero, S., Batista, G.S. and Mazzini, R.B. (2012) Época de coleta e ácido indolbutírico no enraizamento de estacas de espirradeira (Nerium oleander N.). Revista Árvore, 36, 17-23. https://doi.org/10.1590/S0100-67622012000100003

[14] Stuepp, C.A., Bitencourt, J., Wendling, I., Koehler, H.S. and Zuffellato-Ribas, K.C. (2017) Age of Stock Plants, Seasons and IBA Effect on Vegetative Propagation of Ilex paraguariensis. Revista Árvore, 41, e410204.

[15] Pizzatto, M., Wagner Jr., A., Luckmann, D., Pirola, K., Cassol, D.A. and Mazaro, S.M. (2011) Influência do uso de AIB, época de coleta e tamanho de estaca na propagação vegetativa de hibisco por estaquia. Revista Ceres, 58, 487-492. https://doi.org/10.1590/S0034-737X2011000400013

[16] Oliveira, A.F., Chalfun, N.N., Alvarenga, A.A., Vieira Neto, J., Pio, R., Oliveira, D. L. (2009) Estaquia de oliveira em diferentes épocas, substratos e doses de AIB diluído em NaOH e álcool. Ciência e Agrotecnologia, 33, 79-85. https://doi.org/10.1590/S1413-70542009000100011

[17] Biasi, L.A. and Boszczowski, B. (2005) Propagação por estacas semilenhosas de Vitisrotundifolia cvs. Magnolia e Topsail. Revista Brasileira de Agrociência, 11, 405-407. 